
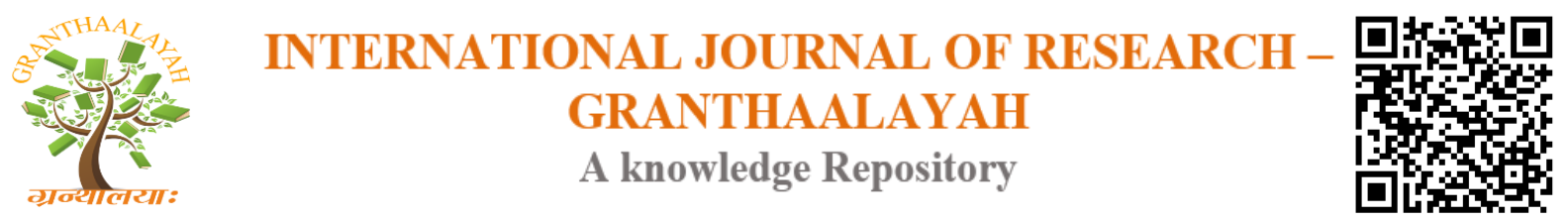

Management

\title{
DEMOCRATIC LEADERSHIP AMONG THE COLLEGE PRINCIPALS
}

\author{
Dr. C. Subathra *1 \\ ${ }^{* 1}$ Assistant Professor of Commerce, Pioneer Kumaraswamy College, Nagercoil -3, INDIA
}

DOI: https://doi.org/10.29121/granthaalayah.v4.i7(SE).2016.2623

\begin{abstract}
The study investigates the Leadership style of college principals in Kanyakumari District. Researches on managers (formal leaders) in different settings suggest that Leadership style, managerial decision-making style, and Motivation profile are the three important factors for managerial effectiveness (Bass, 1990). The study surveyed 130 college principals (51 males and 79 females) in Kanyakumari District. Applied frequency, percentage analysis, Mean and SD to explore the Leadership style of the College Principals in Kanyakumari District using SPSS. The findings of the study reveal that most of the College Principals in Kanyakumari District lead their college in Democratic way.
\end{abstract}

Keywords:

Autocratic, Democratic, Laissez-Faire, Leadership Style.

Cite This Article: Dr. C. Subathra, "DEMOCRATIC LEADERSHIP AMONG THE COLLEGE PRINCIPALS" International Journal of Research - Granthaalayah, Vol. 4, No. 7: SE (2016): 1421.

\section{INTRODUCTION}

Education is the mirror of the society, showing its strength and weakness, hopes, biases and key values of its culture. Education has a definite role to play in the development of people and countries. This may be one of the reasons why United Nations Educational Scientific and Cultural Organizations declare education, a vehicle for and indicator of development. Education and Training play a vital role in assisting individuals and societies to adjust to social, economic and cultural changes and promote the development of the human capital essential for economic growth. Modern education aims at imparting knowledge, skills \& attitude required by the youngsters to become functional in their respective societies. Colleges are therefore indented to serve as agents for developing individual citizens within a country. In essence, colleges are institutions were students are groomed to appreciate what the society in which they live stands for and are equipped in order for them to contribute to the advancement of their society. 
Research on managers (formal leaders) in different settings suggests that Leadership style, Decision-making style, and Motivation are the three important factors for managerial effectiveness (Bass, 1990). The manager, a decision maker and the motivator in the field of higher educational institution is "The principal", who is the chief of the institution. This paper investigates the important dimensions of principals' behavior: i.e., Leadership style. Leadership style describes the behavior of the leader by Autocratic Leadership, Democratic Leadership and Laissez-Faire Leadership.

\section{REVIEW OF LITERATURE}

Smith (1998) asserts that if the task is highly structured and the leader has good relationship with the employees, effectiveness will be high on the part of the employees. His findings further revealed that democratic leaders take great care to involve all members of the team in discussion, and can work with a small but highly motivated team. Schwartz (1987) found a high submissiveness among workers in democratic organizations, but those in autocratic organizations expressed frustration and anger. Bales (1970) found two different categories of specialist in work groups. These are task specialist and social-emotional specialist. The task specialist is concerned with the achievement of the group goals while the social-emotional specialist is concerned with maintaining positive social relationship within the group and motivating the group members to accept the goals of the group. However, a good leader can combine the two roles (Roger \& Roger, 1994). The two categories actually distinguished two different style of leadership namely autocratic and democratic. Lewin et al (1939) concluded that democratic style of leadership is the most effective, but Smith and Peterson (1988) pointed that the effectiveness of group leaders is dependent on the criterion which was being used to assess leadership. Thus, if leadership is assessed in terms of productivity, then autocratic style is most efficient but if the role is seen as maintaining good morale and a steady level of work, democratic style is effective. Absence of leadership style brings about lack of direction from the leader resulting in low morale and lack of interest in the work. Hayers (2000) found that workers who fell under pressure reported autocratic supervision on the part of their leaders. The leaders rarely allowed them to participate in the decision making. It was also reported that workers who were under stress also reported harsh supervision and control on the part of their leaders (Hayers, 2000). The availability of social support, both on and off the job, is a crucial determinant of organizational stress (Cohen \& Wills, 1985).

\section{LEADERSHIP STYLE}

For the purpose of this study the researcher has taken the variable leadership style based on; (Lewin, Lippit and White, 1939). It describes the behavior of the leader by Autocratic Leadership, Democratic Leadership and Laissez-Faire Leadership.

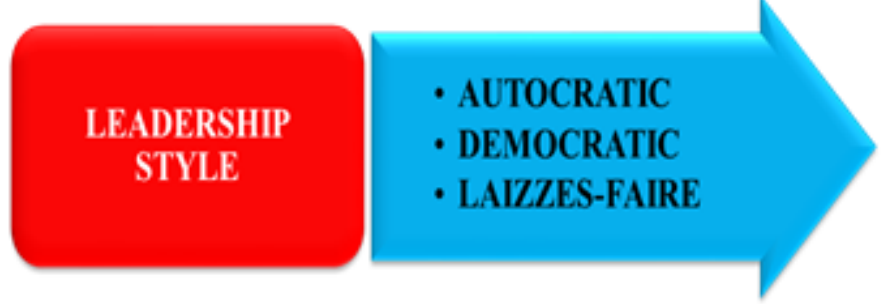

Figure 1: Dimension of Leadership Style 
Leadership style is the distinctive way in which a superior manages her/his interfaces with subordinates. This style is likely to be influenced strongly by the leader's beliefs about how subordinates should be treated. It is likely to manifest itself in aspects such as the nature of a leader's response to the subordinate's mistakes, conflicts between subordinates, the role the leader gives to subordinates in decision-making, the kind of support the leader extends to subordinates, the manner in which the leader assigns tasks, the kind of information she/he shares with subordinates and the way in which it is shared, the opportunities the leader gives to subordinates to take initiative, and the effort the leader makes for the development of subordinates.

The first initiation in the field of leadership styles was in 1939. A group of researchers under the leadership of Kurt Lewin the famous psychologist conducted experiments on different styles of leadership. The experiments were conducted on specific group of school children and the researchers then observed the behavior of children in response to the different styles of leadership. Though recent researchers have identified more specific types of leadership, this early study was very influential and established three major leadership styles. They are Autocratic, Democratic and Laissez-fair. A brief description about these styles is given below.

\section{AUTOCRATIC LEADERSHIP}

Where the leader exercises rigid control and believes in the carrot and stick method to motivate his subordinates. He prefers only one-way communication, i.e., top-down communication. There is one advantage here-the decision making takes less time, but this may antagonize the group members and adversely affect group morale. Autocratic leaders have the clear concept for what to be done, when it should be done, and how it should be done. He keeps the strong boundary between the leader and the followers. Autocratic leaders taking decisions independently without consulting the rest of the group. It is found that decision-making was less creative under Autocratic leadership. According to Lewin it would be more difficult for an Autocratic to make changes in his style. Abuse of this style is usually viewed as controlling, bossy, and dictatorial. Autocratic leadership is best applied to situations where there is little time for group decisionmaking or where the leader is the most knowledgeable member of the group.

\section{DEMOCRATIC LEADERSHIP}

According to Lewin's study democratic style of leadership is considered as the most effective leadership style. Here the leaders offer all helps to group members, and they themselves participating in the group. The leader believes in allowing participatory management and group members are free to give their opinion, decision-making is cooperative and members having a sense of belonging. In Lewin's study, children in this group were less productive than the members of the Autocratic group, but their contributions were of a much higher quality. Participative leaders encourage group members to participate, but retain the final say over the decision-making process. Group members feel engaged in the process and are more motivated and creative. The potential demerit is slower decision-making process. 


\section{LAISSEZ-FAIR LEADERSHIP}

Where the leader avoids contact with the group and there is a free climate and non-interference from the leader. Though the members have freedom, there is no control and group members may try to realize their personal objectives rather than group goals, with the result that group cohesiveness is lost ultimately. Lewin (1939) observed that Delegative leaders offer little or no guidance to group members and leave decision-making up to group members. While this style can be effective in situations where group members are highly qualified in an area of expertise, it often leads to poorly defined roles and a lack of motivation.

\section{OBJECTIVES OF THE STUDY}

The objective of the present study:

- To examine the Leadership style of the College principals in Kanyakumari District.

- To check the level of intensity for Democratic Leadership style among the College principals in Kanyakumari District.

\section{METHODOLOGY}

The present study is conducted in Kanyakumari District, which is a tiny district in Tamil Nadu. The population for the purpose of the study is the College Principals in Kanyakumari District. The researcher has taken five types of colleges in Kanyakumari district viz., Arts \& Sciences $(n=24)$, Engineering Colleges $(n=31)$, Polytechnic Colleges $(n=21)$, Nursing College $(n=20)$ and Education Colleges $(n=34)$ as the target group for the purpose of this study. As the researcher had taken whole population of the target group as a population for the purpose of this study, it is a census survey. This study employed a survey questionnaire. Leadership Style Questionnaire (Lewin, Lippit and White (1939), aims to testing the preference towards Principals' Leadership style by Autocratic, Democratic or Laizzes-faire. To explore the Leadership style of College Principals in Kanyakumari District applied descriptive statistics (mean and percentage) And to check the level of intensity for Democratic Leadership style among the College principals in Kanyakumari District applied frequency and Percentage analysis using SPSS.

\section{ANALYSIS}

\section{MEAN AND SD OF THE LEADERSHIP STYLE}

The values of means of Leadership Style range from 2.88 to 3.50 with standard deviations ranging from 1.43 to 1.54. More detailed in Table.1

Table 1: Mean and Standard Deviation of the Leadership Style

\begin{tabular}{|l|l|l|l|}
\hline Scale & N & Mean & Std. Deviation \\
\hline Autocratic & 130 & 3.41 & 1.434 \\
\hline Democratic & 130 & 3.50 & 1.459 \\
\hline Laizzes-faire & 130 & 2.88 & 1.545 \\
\hline
\end{tabular}

Source: Primary data 
The result of the study reveals that the score of the Autocratic leadership is 3.41. The range of this style is between 1 to 5 . And 3 is the midpoint, 5 is the highest possible score. The Standard Deviation is 1.434. The score of Democratic leadership is 3.50. The range of this style is also between 1 to 5 . And 3 is the midpoint, 5 is the highest possible score. The Standard Deviation is 1.459. The score of Laizzes-faire leadership is 2.88. The range of this style is also between 1 to 5. And 3 is the midpoint, 5 is the highest possible score. The Standard Deviation is 1.434. Thus the result proves that the Democratic styles are predominant among the principal of Kanyakumari District. Figure 2 show it in detail.

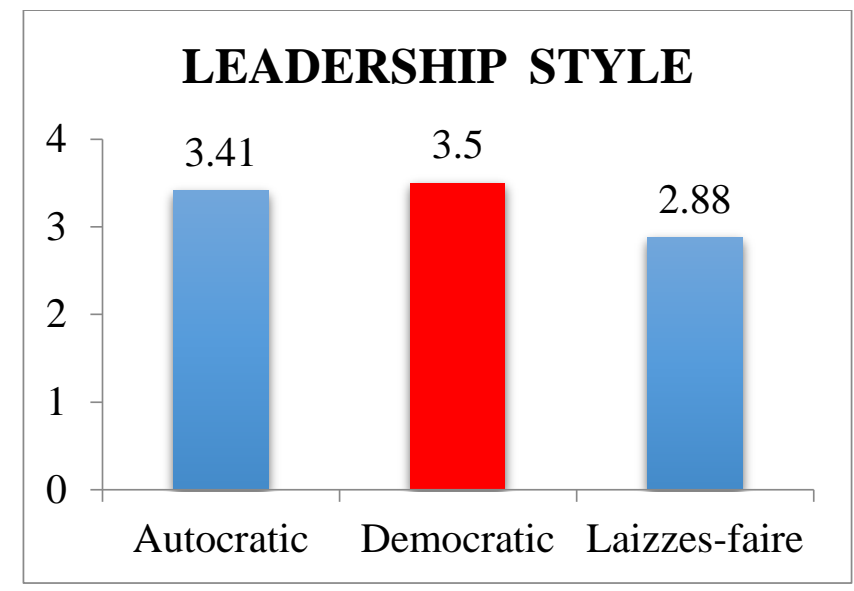

Figure 2: Mean Score of Leadership Style

\section{FREQUENCY AND PERCENTAGE OF LEADERSHIP STYLE}

Table 2 shows that the majority of the respondents $33.1 \%(n=43)$ scored very high range level of intensity for the Democratic leadership style followed by $31.5 \%(n=41)$ in Autocratic leadership style.

Table 2: Leadership Style of the respondent

\begin{tabular}{|c|c|c|c|c|c|c|}
\hline $\begin{array}{l}\text { Leadership } \\
\text { style }\end{array}$ & $\begin{array}{l}\text { Very Low } \\
\text { Range }\end{array}$ & $\begin{array}{l}\text { Low } \\
\text { Range }\end{array}$ & $\begin{array}{l}\text { Moderate } \\
\text { Range }\end{array}$ & $\begin{array}{l}\text { High } \\
\text { Range }\end{array}$ & $\begin{array}{l}\text { Very } \\
\text { High } \\
\text { Range }\end{array}$ & TOTAL \\
\hline Autocratic & $\begin{array}{l}\mathrm{n} \\
(14.6 \%)\end{array}$ & $\begin{array}{l}\text { n } 19 \\
(14.6 \%)\end{array}$ & $\begin{array}{l}\text { n } 23 \\
(17.7 \%)\end{array}$ & $\begin{array}{l}\text { n } 28 \\
(21.5 \%)\end{array}$ & $\begin{array}{l}\text { n } 41 \\
(31.5 \%)\end{array}$ & $\begin{array}{l}130 \\
(100 \%)\end{array}$ \\
\hline Democratic & $\begin{array}{l}\mathrm{n} \\
(16.9 \%)^{22}\end{array}$ & $\begin{array}{l}\mathrm{n} \\
(9.2 \%)\end{array}$ & $\begin{array}{l}\mathrm{n} \quad 18 \\
(13.8 \%)\end{array}$ & $\begin{array}{l}\mathrm{n} \quad 35 \\
(26.9 \%)\end{array}$ & $\begin{array}{l}\mathrm{n} \quad 43 \\
(33.1 \%)\end{array}$ & $\begin{array}{l}130 \\
(100 \%)\end{array}$ \\
\hline $\begin{array}{l}\text { Laissez- } \\
\text { faire }\end{array}$ & $\begin{array}{l}\mathrm{n} \\
(27.7 \%)^{36}\end{array}$ & $\begin{array}{l}\mathrm{n} \quad 26 \\
(20.0 \%)\end{array}$ & $\begin{array}{l}\mathrm{n} \quad 15 \\
(11.5 \%)\end{array}$ & $\begin{array}{l}\text { n } 24 \\
(18.5 \%)\end{array}$ & $\begin{array}{l}\mathrm{n} 29 \\
(22.3 \%)\end{array}$ & $\begin{array}{l}130 \\
(100 \%)\end{array}$ \\
\hline
\end{tabular}

Source: Primary data 
It also shows that $26.9 \%(n=35)$ scored high range level of intensity for the democratic leadership style followed by Autocratic Leadership style. That means the majority of respondents scored within high range and very high range for the Democratic leadership style.

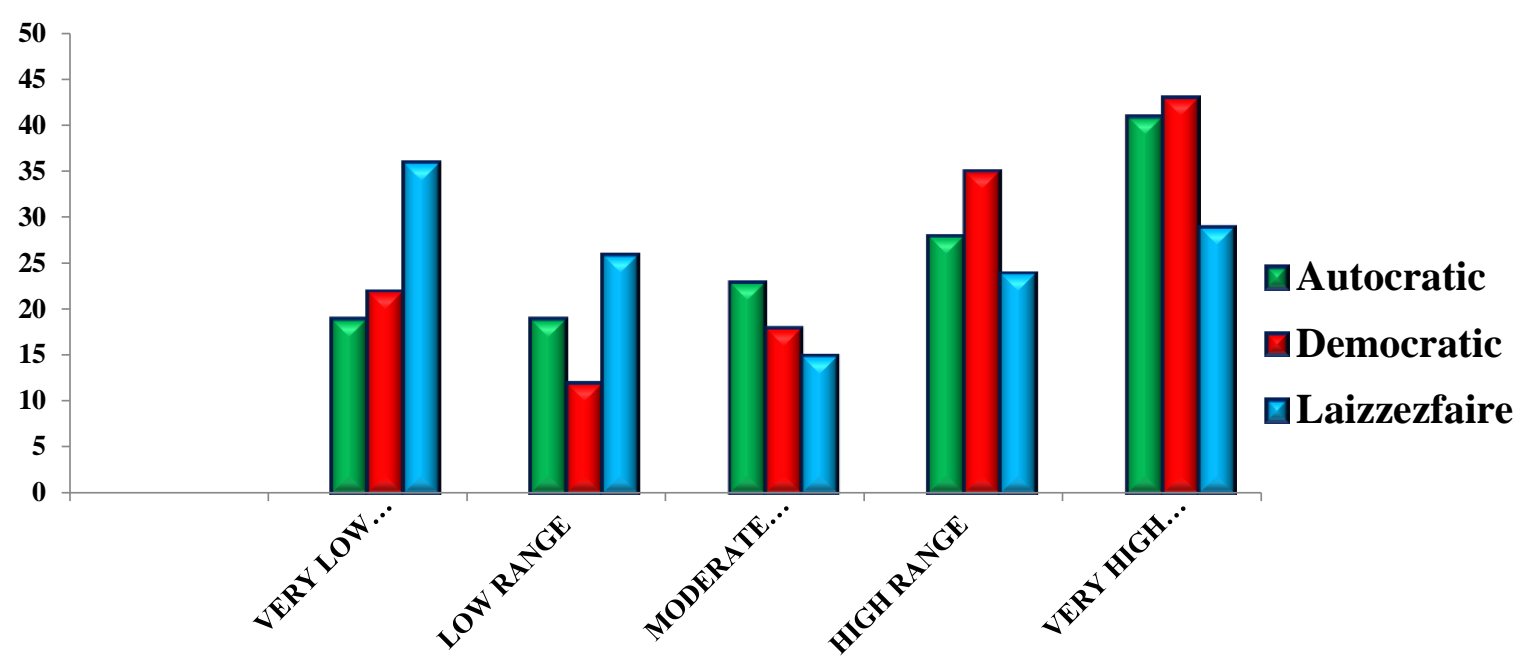

Figure 3: Leadership Style of the college principal

\section{FINDINGS}

- The values of means of Leadership Style range from 2.88 to 3.50 with standard deviations ranging from 1.43 to 1.54 . The result proves that the Democratic styles are predominant among the principal of Kanyakumari District.

- The majority of College Principals, $n=43$ (33.1\%) has scored in the Very high range of intensity for Democratic Leadership style. Comparatively higher than the score of all the other styles. 35 Principals have scored high range of intensity for this style. And only 22 respondents have scored the low range of intensity for this style. It reveals that most of the College Principals in Kanyakumari District lead their college in Democratic way.

\section{SUGGESTIONS}

The researcher made the following suggestions from the findings of the study:

- The researcher suggests that college principals must be aware of different leadership behavior, so that they switch in to the particular style in order to overcome the situation. Some may not be the most effective in all situations or environments; therefore it is suggested that Principals to find ways to take advantage of the benefits provided by the other styles.

- As exist in the higher education, the newly appointed Principal should be given compulsory orientation programme that enable them to face the new challenges in the field of education effectively. This will also ultimately generate in them ideal Leadership qualities.

- The study reveals that less than 50 percent of the college principals are in very high range of intensity for democratic Leadership Styles. That shows that the remaining $50 \%$ or more than $50 \%$ of principals are having a very low level of intensity for these Leadership 
Behaviours. Thus it is suggested that effective leadership training should be given to the college principals in Kanyakumari District focusing on managerial Leadership behavior.

\section{CONCLUSION}

From the study it is clear that the College Principals in Kanyakumari District are not alike in the adoption of their Leadership style. Each Principal has his or her own style. According to Lewin's study democratic style of leadership is considered as the most effective leadership style. Here the leaders offer all helps to group members, and they themselves participating in the group. The leader believes in allowing participatory management and group members are free to give their opinion, decision-making is cooperative and members having a sense of belonging. In Lewin's study, children in this group were less productive than the members of the Autocratic group, but their contributions were of a much higher quality. Participative leaders encourage group members to participate, but retain the final say over the decision-making process. Group members feel engaged in the process and are more motivated and creative.

\section{REFERENCES}

[1] Ash, Ruth. \& Maurice, P., (2001) The Principal as Chief Learning Officer: The New Work of Formative Leadership.

[2] Avolio, B. J. (1999). Full Leadership Development. Thousand Oaks, CA: Sage. www.mlq.com.au/position_feature_article.asp

[3] B. M. (1990). Bass and Stogdill's Handbook of Leadership, (3rd ed). New York: Free Press.

[4] Bales, R. F. (1970). Interaction process analysis. Mass: Addison Wesley, 509.

[5] Bartol, K. M., \& Martin, D. C. (1986). Women and men in task groups. In R.D. Ashmore \& F. K. Del Boca (Eds.), The social psychology of female-male relations (pp. 259-310). Orlando, FL: Academic.

[6] Bass, B. M. (1985a). Leadership and Performance Beyond Expectation. New York: Free Press.

[7] Bass, B. M., \& Avolio, B. J. (1994). Introduction in Bass, B. M., \& Avolio, B. J. (Eds). Improving Organizational Effectiveness through Transformational Leadership, (pp 1-10). Thousand Oaks, CA: Sage.

[8] Beck, T., P. Behr, A. Guettler (2013). Gender and Banking: Are Women Better Loan Officers? Review of Finance. 17: 1279-1321.

[9] Cheaupalakit, Panpim, (2002), The leadership styles of male and female higher education administrators in Thailand. Ph.D., Illinois State University.

[10] Chliwniak, L. (1997). Higher education leadership: Analyzing the gender gap. ASHEERIC Higher Education Report, 25.

[11] Cohen, S., \& Wills, T. A. (1985) Stress, social support and offering hypothesis. Psychology Bulletin, 310-357. http://dx.doi.org/10.1037/0033-2909.98.2.310

[12] Collins, J. (2001). Good to Great. New York: Harper Business.

[13] Eagly, A.H. \& Johnson, B.T. (1990). Gender and leadership style: A meta-analysis. Psychological Bulletin, 108, 233-256.

[14] Golden, S. A. R. (2011). Problems and Prospectus of Distance Learning. Bharathidhasan University, 343, 344. 
[15] Golden, S. A. R. (2011). Strategy For Success Of Human Beings:-Time Management. Department Of BBA, St. Joseph's College, Trichy, 388-390.

[16] Joshi, J., \& Tomar, A. (2003). Leadership in Women, University News, Vol. 41(09), March 3-9, p. 2-4.

[17] Kothari, C.R., "Research Methodology - Methods and Techniques", New Age International Pvt., Publisher, 2006.

[18] Lewin, K., Lipitt. R., \& White, R. K. (1939).Patterns of Aggressive Behavior in Experimentally Created Social Climate, The Journal of Social Psychology, 10, $271-$ 299.

[19] Subathra, C. Decision making style of college principals in Kanyakumari district, International Research Journal of Management and Humanities, Volume 2, Issue 1, June 2014, ISSN No.2347-3274, Pg no.103-113 - Siddharaja Publications.

[20] Subathra, C. Leadership style of college principals in Kanyakumari district - A study, The International Journal for Economics and Business Management, ISSN No.22502750, June 2015, Volume 4, Issue 2, and Pg.No.61-68.

[21] Subathra, C. Leadership Style of Higher Education Leader, Published in "Education in India: Challenges and Perspectives" a Vergal Publications, ISBN No. 978-93-85109-034, Pg no. 345-348, March 2015.

[22] Subathra, C. The relationship between principals' Leadership style and Demographic profile, publications in B-Digest, Contemporary Business Conundrum, Oct 2014, ISBN No.:978-93-84734-04-6, Pg 65-69.

[23] Sutherland, M. B. (1999). Gender equity in success at school. International Review of Education, 45, 431-444.

[24] Thompson, M. D. (2000). Gender, leadership orientation, and effectiveness: Testing the theoretical models of Bolman, Deal, and Quinn. Sex Roles, 42, 969-993. 